\title{
ANALISIS USAHA PENGOLAHAN KOPRA PUTIH DI KECAMATAN TEMBILAHAN (Studi Kasus Lembaga Pelatihan Keterampilan (LPK) Delapan Yes)
}

Gunawan Syahrantau, Agustian Saputra

Program Studi Agribisnis Fakultas Pertanian UNISI

e-mail:syahrantau_gsr@yahoo.co.id

\begin{abstract}
ABSTRAK
Tujuan penelitian adalah : (1) untuk mengetahui keuntungan pengolahan kopra putih di Lembaga Pelatihan Keterampilan (LPK) Delapan Yes di Kecamatan Tembilahan Kabupaten Indragiri Hilir, (2) untuk mengetahui tingkat efisiensi usaha pengolahan kopra putih di di Lembaga Pelatihan Keterampilan (LPK) Delapan Yes di Kecamatan Tembilahan Kabupaten Indragiri Hilir. Penelitian ini dilakukan dengna metode observasi dan wawancara langsung dengan kuisioner. Metode analisis data dalam penelitian ini adalah analisis biaya, penerimaan, keuntungan dan pendapatan kerja dalam keluarga serta efisiensi usaha. Hasil penelitian menunjukkan bahwa : (1) total biaya pada usaha pengolahan kopra putih yaitu biaya tidak tetap sebesar Rp. 12.748.000,00 dan biaya tetap sebesar Rp.3.181.433,33, rata-rata penerimaan yang diperoleh sebesar Rp.25.650.000,00 per produksi, rata-rata keuntungan yang diperoleh adalah sebesar Rp. 9.720.566,67 per produksi dan rata-rata pendapatan kerja keluarga sebesar Rp. 10.220.566,67 per produksi (2) nilai RCR adalah sebesar 1,61 yang berarti usaha pengolahan kopra putih efisien.
\end{abstract}

Kata kunci : Keuntungan , Efisiensi, Kopra Putih.

\section{ABSTRACT}

The research objectives are: (1) to find the profit of white copra at Skills Training Institute (LPK) Delapan Yes in subdistrict of Tembilahan, District of Indragiri Hilir, (2) to determine business efficiency the white copra processing at LPK Delapan Yes. This method of research is observation and direct interviews with questionnaires. The methods of data analysis are analysis of costs, revenues, profits and work income in the family as well as business efficiency. The results of research showed that: (1) the cost in the white copra processing business is a variable cost of Rp. 12,748,000.00 per production and fixed costs of Rp.3,181,433.33 per production, the average revenue $R p$. 25,650,000.00 per production, the average profit $R p$. 9,720,566.67 per production and the average family work income of $R p$. 10,220,566.67 per production (2) the RCR value is 1.61 which means that the efficient processing of white copra.

Keywords : Profit, Efficiency, White Copra

\section{PENDAHULUAN}

Pertumbuhan sektor-sektor lain agar dapat memperbaiki keadaan perekonomian masyarakat. Subsektor perkebunan mempunyai peluang yang sangat besar untuk dijadikan andalan ekspor pembangunan dibidang perkebunan diarahkan untuk lebih mempercepat laju pertumbuhan produksi baik dari perkebunan besar, swasta maupun perkebunan negara. Peranan sektor perkebunan yang demikian besar bagi peningkatan pemanfaatan petani dan penyediaan bahan baku untuk industri dalam negeri 
serta sebagai sumber devisa negara (Widarti dan Sunarli, 2014).

Perkebunan kelapa di Indragiri Hilir menyumbang kontribusi besar 76,24 persen dari 514.774 hektar luas perkebunan kelapa di Provinsi Riau . Kabupaten Indragiri Hilir terkenal dengan perkebunan kelapa yang sangat luas di Riau, dimana pada tahun 2018 terdapat seluas $340.773 \mathrm{Ha}$ areal perkebunan kelapa dengan produksi sebanyak 317.116.870,52 kg. Dari tahun 2015-2018 luas areal dan produksi kelapa cenderung mengalami penurunan. Penurunan luas areal dan produksi terbesar terjadi pada periode 2017-2018 sebesar 10,89\% dengan penurunan produksi sebesar 3,29\%.

Maka dari itu produk-produk turunan dari kelapa sangat dan perlu pengembangan salah satunya yaitu itu kopra. Kopra adalah daging buah yang dikeringkan. Kopra merupakan salah satu produk turunan tanaman kelapa yang sangat penting. Pada tahun 2005, volume ekspor kopra Indonesia hampir mencapai 50.000 ton, dan nilai ekspor kopra menempati peringkat tiga setelah minyak kelapa dan minyak goreng dalam volume dan nilai ekspor produk turunan kelapa (Dirperindag, 2007).

Pengolahan kopra ada dua jenis yaitu pengolah kopra asap danpengolahan kopra putih, Kopra putih adalah kopra hasil pengeringan menggunakan sinar matahari dan oven, kualitaskopra lebih bagus, kadar air kecil dan bersih. Kopra putih dihasilkan dengan proses pengeringan tidak langsung (indirect drying) atau denganmenggunakan mesin pengering. Suhu dan lama pengeringan akan menentukan mutu kopra yangdihasilkan (Agustiani V, Burhan dan Rahman A. 2014)

Salah satu usaha pengolahan kopra putih yang ada di Kecamatan Tembilahan yaitu LPK Delapan Yes.
Harga kopra putih pada bulan Maret 2020 yaitu berkisar sebesar Rp. 7.50011.000 per $\mathrm{kg}$, sedangkan harga kelapa butiran pada bulan november berkisar sebesar Rp. 1.200 per kg. Hal tersebut menyebabkan pelaku usaha mengolah kelapa dalam bentuk kopra putih.Analisis usaha sangat penting dilakukan bagi pelaku usaha dalam menjalankan usahanya guna peningkatan keuntungan serta pengembangan usaha. Tujuan dari penelitian ini adalah 1) menganalisis berapa besar keuntungan dari usaha pengolahankopra putih di LPK Delapan Yes, 2) menganalisis tingkat efisiensi usaha pengolahankopraputihdi LPK Delapan Yes.

\section{METODOLOGI PENELITIAN 2.1 Waktu dan Tempat Penelitian}

Penelitian ini dilakukan di Usaha Pengolahan Kopra Putih Delapan Yes. Penentuan lokasi penelitian ini dipilih secara purposive (sengaja) dengan pertimbangan yaitu usaha tersebut merupakan salah satu yang produksinya cukup besar di wilayah Tembilahan, penelitian ini dilakukan selama kurang lebih 3 bulan yaitu pada bulan Januari sampai dengan bulan Maret 2020.

\subsection{Jenis dan Sumber Data}

Sumber data yang diperlukan pada penelitian ini adalah :

a. Data Primer di peroleh dengan cara melakukan wawancara kepada pelaku usaha pengolahankopra putih di LPK Delapan Yes dengan panduan pertanyaan yang sudah disiapkan, biasanya disebut dengan kuisioner.

b. Data Sekunderdiperoleh dari studi literatur yang relevan dengan penelitian ini seperti buku, skripsi, jurnal, internet,dan sebagainya. 


\subsection{Metode Pengambilan Data}

1. Observasi lapangan dengan melakukan pengamatan langsung ke tempat lokasi usaha pengolahan kopra putih dLPK Delapan Yes .

2. Wawancara yaitu metode pengumpulan data dengan cara melakukan wawancara langsung kepada responden (pengusaha kopra putih) menggunakan kuesioner yang telah disiapkan

\subsection{Metode Analisis Data}

\section{Biaya Produksi}

Melakukan kegiatan usaha agroindustri ada biaya yang dikeluarkan yaitu biaya tetap (FC) dan biaya variabel (VC). Untuk mengetahui total biaya produksi secara matematis dirumuskan sebagai berikut :

$$
\mathbf{T C}=\mathbf{F C}+\mathrm{VC}
$$

Keterangan :

$$
\begin{aligned}
& \mathrm{TC}=\text { Total } \text { Cost }(\mathrm{Rp} / \text { Produksi }) \\
& \mathrm{FC}=\text { Fix } \text { Cost }(\mathrm{Rp} / \text { Produksi }) \\
& \mathrm{VC}=\text { Variabel Cost }(\mathrm{Rp} / \text { Produksi })
\end{aligned}
$$

Pendekatan pengeluaran atau biaya yang dilakukan selama satu kali produksi dalam sebulan adalah dengan mengakumulasikan pengeluaran selama satu kali produksi selama 30 hari. Asumsinya adalah pengeluaran yang dilakukan selama satu kali produksi selalu sama.

\section{Penyusutan Alat}

Untuk menghitung biaya penyusutan alat dalam usaha tani dihitung dengan metode garis lurus menurut Sinuraya (1985). Dengan rumus sebagai berikut:

$$
\mathbf{D}=\frac{\mathbf{C}-\mathbf{S V}}{\mathbf{U L}}
$$

Keterangan :

D : Nilai penyusustan alat

C : Harga beli alat

SV : Nilai sisa $(20 \% \times$ nilai beli)
UL : Masa pakai

\section{Penerimaan}

Penerimaan usaha agroindustri adalah perkalian antara jumlah produksi yang diperoleh dengan harga yang berlaku dipasar (Soekartawi, 1998). Jadi, penerimaan yang didapat pengusaha kopra putih adalah merupakan perkalian antara jumlah produksi kopra putih dikali dengan harga yang berlaku dipasaran. Secara matematis rumusnya adalah sebagai berikut:

$$
\mathbf{T R}=\mathbf{Q} \times \mathbf{P}
$$

Keterangan :

$\mathrm{TR}=$ Total Revenue (Rp/Produksi)

$\mathrm{Q}=$ Quantity $(\mathrm{Kg} /$ Produksi)

$\mathrm{P}=$ Price $(\mathrm{Rp} / \mathrm{Kg})$

Dengan rumus diatas maka hasil dari penjualan kopra putih yang didapat merupakan fungsi dari jumlah produksi kopra putih yang terjual dengan harga yang berlaku dipasar. Pendekatan yang dilakukan dalam penelitian ini adalah dengan cara melakukan wawancara selama 2-3 kali dalam seminggu. Asumsinya adalah pendapatan selama 2-3 kali wawancara diakumulasikan dalam 30 hari kerja atau sebulan kerja.

\section{Pendapatan Kerja Keluarga}

Menurut Hernanto (1991), untuk menghitung pendapatan keluarga digunakan rumus sebagai berikut:

$$
\text { PKK }=\pi+\text { TKDK }+ \text { D }
$$

Keterangan :

PKK : Pendapatan Kerja Keluarga (Rp/Produksi/Th)

$\pi \quad$ : Keuntungan(Rp/Produksi)

TKDK : Upah tenaga kerja dalam keluarga (Rp/Produksi)

D : Penyusustan Alat 


\section{Keuntungan}

Keuntungan adalah selisih penerimaan total denganbiaya total. Dapat ditulis dengan rumus sebagai berikut :

$$
\pi=\mathbf{T R}-\mathbf{T C}
$$

Keterangan :

$\pi$ : Keuntungan pengolahan kopra putih(Rp/Produksi)

TR : Total penerimaan usaha (Rp/Produksi)

TC : Biaya totalusaha (Rp/Produksi)

\section{Efisiensi}

Menurut Soekartawi (2002), analisis Return Cost (R/C) ratio merupakan perbandingan (ratio atau nisbah) antara penerimaan (revenue) dan biaya (cost). yang dikeluarkan dalam satu kali produksi. Untuk mengetahui efisiensi, maka rumus yang dipakai yaitu:

\section{Efisiensi $=\mathbf{R} / \mathbf{C}$}

Keterangan :

$\mathrm{R}=$ Penerimaan total usaha dagang

(Rp/Produksi)

$\mathrm{C}=$ Total biaya yang dikeluarkan

(Rp/Produksi)
Kriteria yang digunakan dalam penilaian efisiensi usaha adalah :

- R/C Ratio > 1, Usaha pengolahan kopra putih dinyatakan layak.

- $\mathrm{R} / \mathrm{C}$ Ratio = 1 , Usaha pengolahankopra putih dinyatakan berada pada titik impas.

- $\mathrm{R} / \mathrm{C}$ Ratio < 1, Usaha pengolahankopra putih tidak layak.

\section{HASIL DAN PEMBAHASAN 3.1. Teknik Pengolahan Kopra Putih}

Kegiatan produksi usaha pengolahan kopra putih di Lembaga Pendidikan Keterampilan (LPK) Delapan Yes merupakan kegiatan usaha yang dilakukan setiap hari. Bahan baku utama dalam usaha pengolahan kopra putih adalah kelapa bulat yang di beli dari para petani kelapa yang langsung di antarkan ke tempat produksi. Untuk kelapa yang di gunakan bermacammacam seperti kelapa hibrida dan kelapa dalam dengan keadaan yang baik dan umur buah yang telah sesuai.

Teknik pengolahan kopra putih pada umumnya hampir sama dengan pengolahan kopra sebelumnya yang menggunakan asap. Adapun langkahlangkah dan gambar skemanya sebagai berikut:

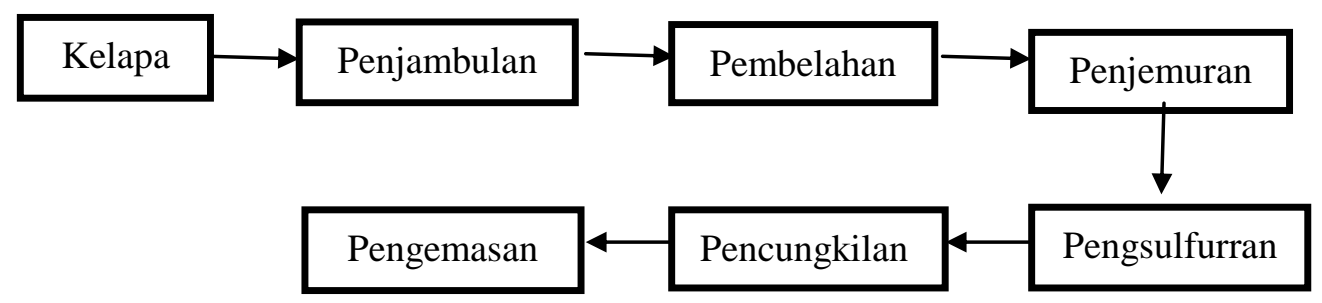

Gambar 1. Skema Teknik pengolahan Kopra putih di Lembaga Pendidikan Keterampilan (LPK) Delapan Yes

1. Kelapa bulat yang telah dibeli kemudian di kumpulkan pada satu titik, dibersihkan terlebih dahulu bagian jambul kelapa agar menghemat tempat dan memudahkan pada proses pembelahan, kemudian para pekerja membelah kelapa tersebut menjadi dua bagian sama rata menggunakan parang kecil, air dari kelapa tersebut di tampung kedalam baskom, dan air inilah yang digunakan untuk membersihkan bagian dalam kelapa jika dirasa ada lendir jika tidak ada diperlu dibersihkan, lalu kelapa yang sudah di belah di tiriskan 
kedalam keranjang hingga penuh dengan posisi tertungkup.

2. Setelah kelapa yang di ditiriskan sementara di dalam keranjang lalu di masukkan kedalam green house yang di buat khusus menggunakan plastikuv dengan ketebalan yang menyesuaikan untuk pengeringan kelapa yang sudah di belah tersebut. Kelapa yang didalam keranjang di keluarkan dan disusun rapi dengan posisi daging kelapa menghadap ke atas untuk mendapat pengeringan dari cahaya matahari secara optimal.

3. Proses pengeringan dilakukan selama 4 hari agar memudahkan dalam pengcungkilan daging kelapa dengan batok kelapa. Pada proses pengeringan juga di berikan foging sulfur atau pengasapan belerang yang bertujuan untuk mencegah jamur tumbuh di kopra dan untuk meningkatkan kualitas dari kopra tersebut, ini dilakukan pada malam hari selama proses pengeringan.

4. Setelah proses pengeringan selesai, kopra di cungkil menggunakan alat khusus, kemudian dilakukan pengcutingan atau pemotongan sedikit bagian kelapa yang apabila ada bagian yang dirasa agak berlebihan dan untuk mempercantik bentuk kopra tersebut setelah itu kopra di kemas kedalam karung dan siap untuk di jual.

\subsection{Faktor Produksi}

\section{Tempat Usaha}

Dalam menjalankan suata usaha tentunya harus ada tempat agar usaha yang dilakukan dapat berjalan. Untuk usaha Pak Yan Ekhsan ini menggunapan beberapa bangunan seperti bangunan semi permananen yang memudahkan dalam proses pengolahan kopra putih dan green house yang digunakan untuk pengeringan kopra, yang sangat praktis misal ketika hujan turun proses pengeringan tetap berlanjut tanpa harus repot repot untuk menutupi kopra dengan plastik penutup atau terpal.

\section{Modal}

Setiap usaha tentu membutuhkan modal untuk membiayai kegiatan operasional usaha sehari-hari baik itu untuk investasi maupun keperluan lainnya. Besarnya modal diperlukan akan berbeda sesuai dengan besar kecilnya skala usaha. Menurut Heranto (1989) modal merupakan unsur pokok dalam suatau usaha yang digunakan untuk merubah pendapatan, modal usaha diklarifikasikan sebagai kekayaan utama baik dalam bentuk uang maupun barang yang digunakan untuk produksi. Modal pada usaha pengolah kopra putih antara lain bahan baku, pengemasan dan alat produksi.

1. Bahan baku

Bahan bakumerupakan bahan mentah yang menjadi dasar pembuatan suatu produk yang mana bahan tersebut dapat diolah melalui proses tertentu untuk dijadikan wujud yang lain. Bahan baku dari kopra putih adalah kelapa, dimana kelapa mengalami tahapan-tahapan dari pembelahan, pembersihan, pengasapan menggunakan sulfur/belerang ketika dikeringkan kemudian menghasilkan kopra putih yang berkualitas.

2. Peralatan

Peralatan merupakan alat-alat yang digunakan dalam melakukan proses produksi. Pada proses pengolahan kopra putih alat produksi yang di gunakan yaitu, pisau, parang kecil, keranjang, baskom, pengcungkil/kekuit, karung waring, batu asah, angkong dan timbangan yang dapat di jelaskan sebagai berikut : 
a. Pisau

Pisau adalah alat yang digunakan untuk mengiris/memotong yang terbuat dari logam pipih yang tepinya dibuat tajam. Pada proses pengolahan kopra putih dibutuhkan untuk memotong dan merapikan bagian kopra putih yang telah kering.

b. Parang kecil

Parang kecil sama halnya dengan pisau namun agak dibuat tebal agar memudahkan dalam proses memotong benda yang memiliki kulit agak tebal dan untuk pengolahan kopra putih parang kecil digunakan untuk membelah kelapa menjadi dua bagian.

c. Keranjang

Keranjang terbuat dari plastic digunakan untuk meletakan bahanbahan. Pada proses pengolahan kopra putih digunakan untuk meletakan kelapa yang telah dibelah sembari mengurangi kadar air pada kelapa.

d. Baskom

Baskom terbuat dari plastic yang di gunakan untuk menampung air atau benda cair lainnya, pada proses pengolahan kopra putih digunakan sebagai tempat menampung air kelapa pada proses membelah kelapa yang mana air kelapa tersebut digunakan untuk membersihkan bagian dalam kelapa yang masih kotor atau berlendir.

e. Pengcungkil/kekuit

Pencungkil/kekuit adalah alat yang terbuat dari besi yang dibentuk khusus. Pada proses pengolahan kopra putih, pengcungkil digunakan untuk memudahkan memisahkan daging kelapa yang telah kering dengan batoknya.

\section{f. Karung waring}

Karung waring adalah kantong besar yang terbuat dari plastik yang digunakan membungkus. Karung waring digunakan untuk proses pengemasan kopra putih, karung waring dipilih karena memiliki pori pori yang baik untuk sirkulasi udara sehingga kualitas kopra dapat terjaga dengan baik.

g. Batu asah

Batu asah berguna untuk menajamkan pisau dan parang kecil yang berkali kali dipakai pada proses pengolahan kopra putih.

h. Angkong

Angkong atau gerobak dorong yang digunakan untuk memudahkan dalam proses pengangkutan kopra putih.

i. Timbangan

Timbangan merupakan alat yang dipakai untuk melakukan pengukuran massa suatu benda. Pada usaha pengolahan kopra putih timbangan digunakan untuk mengukur kepala bulat dari petani dan kopra putih yang akan dijual sesuai dengan permitaan pembeli.

\section{Tenaga Kerja}

Tenaga kerja adalah semua orang bersedia untuk sanggup kerja (Sumarsono, 2009). Artinya bahwa semua orang yang melakukan kegiatan pekerjaan untuk diri sendiri atau orang lain tanpa menerima upah atau mereka yang sanggup bekerja. Pada usaha pengolahan kopra putih di LPK delapan YES Kecamatan Tembilahan, sebagian besar tenaga kerja berasal dari luar keluarga dan ada juga yang berasal dari dalam keluarga. Tenaga kerja luar keluarga diberi upah sesuai dengan pekerjaan yang telah dilakukan.

\subsection{Analisis Usaha Pengolahan Kopra Putih}

\section{Biaya Produksi}

Biaya produksi merupakan biaya yang dikeluarkan oleh pengusaha kopra putih selama melakukan kegiatan 
usahanya dimulai dari proses produksi hingga menghasilkan produk, yang meliputi biaya tetap dan biaya tidak tetap. Menurut Bambang (2006), biaya tetap adalah biaya yang relative tetap jumlahnya, dan terus dikeluarkan walaupun produksi yang diperoleh banyak atau sedikit sedangkan biaya tidak tetap adalah biaya yang besar kecilnya dipengaruhi oleh proses produksi yang diperoleh. Rincian biaya produksi yang dikeluarkan dalam usaha pengolahan kopra putih di LPK Delapan Yes dapat di lihat pada Tabel 1

\begin{tabular}{|c|c|c|c|c|c|}
\hline No & Komponen & Satuan & Volume & Harga (Rp) & Jumlah(Rp) \\
\hline \multirow[t]{9}{*}{ I } & Biaya tetap & & & & \\
\hline & a. Tenaga Kerja & & & & $2.900 .000,00$ \\
\hline & 1.Tenaga Kerja Luar & & & & \\
\hline & Keluarga & $\mathrm{Rp}$ & 3 & 800.000 & $2.400 .000,00$ \\
\hline & 2. Tenaga Kerja Dalam & & & & \\
\hline & Keluarga & $\mathrm{Rp}$ & 1 & 500.000 & $500.000,00$ \\
\hline & b. Penyusunan Alat & $\mathrm{Rp}$ & & & $29.350,00$ \\
\hline & c. Tempat & $\mathrm{Rp}$ & & & $252.083,33$ \\
\hline & & & & & $3.181 .433,33$ \\
\hline \multirow[t]{9}{*}{ II } & Biaya Tidak Tetap & & & & \\
\hline & a. Kelapa Bulat & $\mathrm{Kg}$ & 10.000 & 1.200 & 12.000.000,00 \\
\hline & b. Belerang & $\mathrm{Kg}$ & 3 & 10.000 & $30.000,00$ \\
\hline & c. Biaya Pengemasan & & & & \\
\hline & - Karung waring & Buah & 45 & 1.600 & $72.000,00$ \\
\hline & - Tali Plastik/Rapia & Buah & 3 & 7.000 & $21.000,00$ \\
\hline & d. Transportasi Pengiriman & $\mathrm{Kg}$ & 2.500 & 250 & $625.000,00$ \\
\hline & & & & & $12.748 .000,00$ \\
\hline & Total & & & & $15.929 .433,33$ \\
\hline
\end{tabular}

Sumber : Data Primer diolah, 2020

\section{a. Biaya Tetap}

Biaya Tetap adalah biaya yang relatif jumlahnya dan harus dikeluarkan walaupun produk yang dihasilkan banyak atau sedikit (Soekartawi, 1995). Pada Tabel 1 menunjukkan bahwa biaya tetap terdiri dari tenaga kerja sebesar Rp. 2.900.000,00/Produksi, biaya penyusutan sebesar Rp. 29.350,00/Bulan dan biaya penyusutan tempat Rp. 252.083,33/bulan sehingga dapat diketahui biaya tetap sebesar Rp. 3.181.433,33/Produksi. Biaya penyusutan yang ini dihitung dari masing-masing peralatan yang ditentukan oleh banyaknya masingmasing alat yang digunakan dan umur ekonomisnya. Biaya penyusutan yang dimaksud disini adalah penyusutan alatalat yang digunakan dalam pengolahan kopra yang dihitung dalam periode per produksi.

Dan dapat disimpulkan bahwa kontribusi terbesar pada biaya tetap adalah biaya tenaga kerja.

\section{b. Biaya Tidak Tetap}

Biaya tidak tetap adalah biaya yang berubah-ubah tergantung dari besar kecilnya produksi yang dihasilkan (Soekartawi,1995). Biaya variable dalam usaha pengolahan kopra putih terdiri dari biaya bahan baku, belerang, biaya pengemasan dan pengiriman. 
Tabel 1 menujukkan bahwa biaya tidak tetap dari usaha pengolahan kopra putih terdiri dari biaya bahan baku sebesar Rp. 12.000.000,00/Produksi, bahan baku yaitu kelapa bulat. belerang $\mathrm{Rp}$. 30.000,00/Produksi, biaya pengemasan berupa karung waring sebesar Rp. 72.000,00, tali plastik/rapia sebesar Rp. 21.000,00 dan yang terakhir biaya transportasi pengiriman sebesar $\mathrm{Rp}$. 625.000,00/Produksi.

Memperhatikan data diatas dapat ditarik kesimpulan bahwa kontribusi terbesar pada biaya tetap adalah bahan baku. Maka dari itu dapat diketahui biaya tidak tetap sebesar Rp. 12.748.000,00/Produksi.

Berdasarkan data diatas dapat disimpulkan bahwa kontribusi terbesar pada biaya tidak tetap adalah bahan baku. Hal ini senada dengan penelitian yang dilakukan Farida Basir Kalai (2018) bahwa kontribusi terbesar pada biaya variabel adalah biaya bahan baku.

\section{c. Total Biaya}

Menurut Soekartawi (1995), total biaya adalah keselurahan biaya tetap ditambah dengan biaya tidak tetap. Biaya Total merupakan yang dikeluarkan pengusaha pengolahan kopra putih. Dari Tabel 1 memperlihatkan bahwa total biaya usaha pengolahan kopra putih didaerah penelitian adalah rata-rata sebesar Rp. 15.929.433,33 per produksi dimana jumlah biaya tetap rata-rata sebesar Rp. 3.181.433,33 dan biaya tidak tetap sebesar Rp. 12.748.000,00 per produksi. Dapat disimpulkan bahwa biaya yang berkontribusi besar adalah biaya tidak tetap, hal ini dikarenak biaya tidak tetap yang dikeluarkan beraneka ragam.

\section{Penerimaan}

Penerimaan usaha pengolahan kopra putih di LPK Delapan YES Kecamatan Tembilahan yang tersaji pada tabel berikut ini.

Tabel 2. Penerimaan Usaha Pengolahan Kopra Putih di LPK Delapan Yes Kecamatan Tembilahan.

\begin{tabular}{clrrr}
\hline No. & Hasil Produksi & $\begin{array}{c}\text { Produksi } \\
(\mathrm{kg})\end{array}$ & Harga (Rp) & Pendapatan (Rp) \\
\hline 1 & Kopra Putih Grade A & 800 & $11.000,00$ & $8.800 .000,00$ \\
2 & Kopra Putih Grade B & 1500 & $8.500,00$ & $12.750 .000,00$ \\
3 & Kopra Putih Grade C & 200 & $5.500,00$ & $1.100 .000,00$ \\
4 & Batok Kelapa & 2500 & 1200,00 & $3.300 .000,00$ \\
& Jumlah & 2.000 & & $25.650 .000,00$ \\
\hline
\end{tabular}

Sumber : Data primer diolah, 2020

Penerimaan usaha agroindustri adalah perkalian antar jumlah produksi yang diperoleh dengan harga yang berlaku dipasar (Sorkartawi,1998). Penerimaan yang diterima oleh pengusaha adalah perkalian antara jumlah produksi kopra putih yang dihasilkan dengan harga kopra putih yang telah ditetapkan.
Pada Tabel 2 dapat kita lihat bahwa penerimaan yang diperoleh yaitu sebesar Rp. 25.650.000,00/Produksi yang merupakan hasil perkalian dari jumlah produksi kopra putih dengan harga yang disesuaikan dengan grade atau kualitas yaitu grade A,B,C dan di tambah dengan batok kelapa. Untuk grade A sebesar Rp. 11.000,00, grade B 
sebesar Rp. 8.500,00 dan C sebesar Rp 5.500,00.

Adapun untuk mengetahui pengklasifikasian kopra berdasarkan grade menurut Lembaga Pelatihan Keterampilan (LPK) Delapan Yes yaitu : Grade A memiliki kadar air yang lebih sedikit.

Tabel 3. Komposisi penerimaan, keuntungan dan efisiensi usaha pengolahan kopra di LPK Delapan YES per Produksi.

\begin{tabular}{|c|c|c|}
\hline No & Uraian & Jumlah (Rp) \\
\hline 1 & Total Biaya & $15.929 .433,33$ \\
\hline 2 & Penerimaan & $25.650 .000,00$ \\
\hline 3 & Keuntungan & $9.720 .566,67$ \\
\hline 4 & Pendapatan kerja dalam keluarga & $10.220 .566,67$ \\
\hline
\end{tabular}

Sumber : Data Primer diolah, 2020

Keuntungan yang diperoleh usaha merupakan selisih antara total penerimaan dengan total biaya yang dikeluarkan. Untuk mengetahui besarnya keuntunganpada usaha pengolahan Kopra Putih di LPK Delapan YES Kecamatan Tembilahan dapat dilihat pada Tabel 3 yang menunjukkan bahwa keuntungan yang diperolah sebesar Rp. 9.720.566,67 Per Produksi. Menurut Hernanto (1998), berhasil tidaknya usaha dapat dilihat dari besarnya pendapatan yang diperoleh dalam mengelola suatu usaha. Bagi pengusaha analisis ini membantu mereka dalam mengukur apakah kegiatan usaha mereka pada saat ini berhasil atau tidak.

\section{Pendapatan kerja dalam keluarga}

Pendapatan kerja keluarga merupakan imbalan terhadap bunga harta sendiri, upah tenaga kerja keluarga, dan besarnya penghasilan

\author{
Keuntungan \\ Komposisi \\ penerimaan, \\ keuntungan dan efisiensi usaha \\ pengolahan Kopra Putih di LPK \\ Delapan YES Kecamatan Tembilahan \\ yang tersaji pada tabel 3 .
}

yang diperoleh. Pada Tabel 3 dapat dilihat juma pendapatan kerja dalam keluarga rata rata sebesar Rp. 10.220.566,67 per produksi. Pendapatan kerja keluarga diperoleh dari pendapatan bersih ditambah dengan upah tenaga kerja dalam keluarga dan penyusutan alat. Menurut Tohir (1983), Keberhasilan atau kesuksesan usaha dapat dilihat dari sudut ekonomi yaitu besarnya penghasilan atau pendapatan kerja keluarga.

\section{Efisiensi}

Efisiensi usaha adalah gambaran layak tidaknya usaha tersbut dilakukan atau diusahakan. Menurut Soekartawi (2002), Analisis Return Cost (R/C) ratio merupakan perbandingan (ratio atau nisbah) antara penerimaan (revenue) dan biaya (cost) yang dikeluarkan dalam satu kali produksi. Analisis Efisiensi usaha pengolahan kopra putih tersaji pada Tabel 4.

Tabel 4. Analisis Usaha Pengolahan Kopra Putih.

\begin{tabular}{clr}
\hline No & \multicolumn{1}{c}{ Uraian } & Jumlah (Rp) \\
\hline 1 & Total Penerimaan & $25.650 .000,00$ \\
2 & Total Biaya & $15.929 .433,33$ \\
& Efisiensi Usaha & 1,61 \\
\hline \multicolumn{2}{r}{ Sumber : data primer diolah tahun 2020 }
\end{tabular}


Dari tabel 4 dapat dilihat bahwa usaha pengolahan kopra putih di daerah

penelitian layak diusahakan, hal ini dapat dilihat dari besarnya $\mathrm{R} / \mathrm{C}$ yang diperoleh yaitu sebesar 1,61 yang berarti bahwa setiap Rp. 1 biaya yang dikeluarkan untuk usaha pengolahan kopra putih akan menghasilkan pendapatan kotor atau penerimaan sebesar Rp. 1.61 dan pendapatan bersih atau keuntungan sebesar Rp. 0,61 . Hal ini senada dengan penelitian yang dilakukan oleh Kalai (2018), nilai RCR yang diperoleh sebesar 1,76 yang berarti usaha pengolaha kopra menguntungkan.

\section{KESIMPULAN DAN SARAN}

\subsection{Kesimpulan}

1. Rata-rata penerimaan yang diperolah sebesar Rp. 25.650.000,00 per produksi, sedangkan rata-rata total biaya yang dikeluarkan adalah sebesar Rp. 15.929.433,33 per produksi sehingga diperoleh keuntungan rata-rata sebesar Rp. 9.720.566,67 per produksi.

2. Nilai efisiensi atau $\mathrm{R} / \mathrm{C}$ yang diperoleh adalah sebesar 1,61 yang berarti bahwa setiap Rp. 1 biaya yang dikeluarkan untuk usaha pengolahan kopra putih akan menghasilkan pendapatan kotor atau penerimaan sebesar Rp. 1,61 dan pendapatan bersih atau keuntungan sebesar Rp. 0,61. Hal ini menunjukkan bahwa usaha pengolahan kopra putih di LPK Delapan YES Kecamatan Tembilahan efisien atau layak diusahakan.

\subsection{Saran}

1. Agar terus mempertahankan kualitas dari produksi kopra putih karena kualitas sangat mempengaruhi dari harga kopra putih tersebut.

2. Diharapkan kepada pemerintah untuk lebih memberikan perhatian terhadap penyediaan modal atau pembinaan terhadap pengusaha dan masyarakat sekitar atau pun diluar kecamatan tembilahan sehingga dapat meningkatan pendapatan petani kelapa dan pengusaha kopra putih khususnya.

\section{DAFTAR PUSTAKA}

Agustiani V, Burhan dan Rahman A. 2014. Optimasi Suhu Dan Waktu Pengeringan Kopra Putihdengan Pemanasan Tidak Langsung (Indirect Drying).

Amin, S. 2009. Cocos Nucifera pengertian dari Kelapa. Edisi Pertama. Yogyakarta

Badan Pusat Statistik. 2019. Inhil dalam Angka. Tembilahan

Badan Pusat Statistik. 2019. Kecamatan Tembilahan Dalam Angka.

Hernanto, F. 1991. Ilmu Usaha Tani. PT. Penebar Swadaya. Jakarta

Kalai, Farida Basir. 2018. Analisis Pendapatan Petani Pengolah Kopra Di Desa Pusungi Kecamatan Ampana Tete Kabupaten Tojo Una-Una.

Media Industri. 2011. http://arifh.blogdetik.com/produ 
ksi-kopra-putih-meningkatkannilai-tambah-bagi-petani/.

diakses pada tanggal 5 Mei 2012

Statistik Perkebunan Indonesia. 2017. Statistik Perkebunan Indonesia Komoditas Kelapa. http://ditjenbun.pertanian.go.id. Diakses tanggal 09-09-2017.

Soekartawi. 1998. Analisis Usahatani. UI-Press, Jakarta.
Soekartawi. 2002. Prinsip Dasar Ekonomi Pertanian: Teori Dana Aplikasinya. Raja Grafindo Persada, Jakarta

Widarti. S dan Sunarli. L. E. 2014. Analisis Pendapatan Petani Kelapa Dalam Di Desa Jeruju Besar Kecamatan Sungai Kakap Kabupaten Kubu Raya. J. Ilmiah Agr IBA. 